\title{
Imagination and Thematic Reality in the African Novel: A New Vision for African Novelists
}

\author{
Abdoulaye Hakibou \\ Language Department, University of Parakou, Parakou, Benin \\ Email: hakibouabdoulaye@yahoo.fr
}

How to cite this paper: Hakibou, A. (2018). Imagination and Thematic Reality in the African Novel: A New Vision for African Novelists. Advances in Literary Study, 6, 8-18.

https://doi.org/10.4236/als.2018.61002

Received: October 17, 2017

Accepted: December 18, 2017

Published: December 21, 2017

Copyright $\odot 2018$ by author and Scientific Research Publishing Inc. This work is licensed under the Creative Commons Attribution International License (CC BY 4.0). http://creativecommons.org/licenses/by/4.0/

\begin{abstract}
The present study on the topic "Imagination and thematic reality in the African novel: a new vision to African novelists" aims to show the limitation of the contribution of the African literary works to the good governance and development process of African countries through the thematic choices and to propose a new vision in relation to those thematic choices and to the structural organisation of those literary works. The study is carried out through the theory of narratology by Genette (1980) and the narrative study by Chatman (1978) as applied to the novels by Chinua Achebe, essentially on the notion of order by Genette and the elements of a narrative by Chatman. It is a thematic and structural analysis that helps the researcher to be aware of the limitation of the contribution of African fiction to the good governance of African States and their real development, for the reason that themes and the structural organisation of those works are past-oriented. In such a context, readers are supposed to decode the different messages so as to put forth the necessary behaviour from the depicted ones. But, when one compares the literary effort of the novelists with the actual positive change, one realises that the gap is still obvious. This brought the researcher to the proposal of a new thematic orientation that does not depict societal misbehaviour but rather builds an ideal society in which the character embodies what the African society should be, African society which is here our particular concern so as to be able to make up the challenge of globalisation. This is not to deny the "fictionality" of the novels, but to reinforce it with stories that are not only past-oriented. This change may constitute a new source of attraction for African future literary works.
\end{abstract}

\section{Keywords}

Narratology, Narrative Structure, Thematic Choice, Structural Organisation, 
Depicting

\section{Introduction}

The notion of theme in relation with a fictional work is the indispensable stepping stone to coherence, to communicability and to the entire writing approach. In a text, the theme is the crossroad where the different technical aspects should lead to. The concept of theme, in the space of the work, is one of the meaning units, one of the categories of the presence acknowledged as particularly being active. Defined this way, the theme designates, in a work, all that is a peculiarly significant indication of a world existent created by the writer. From this definition, one can consider the theme as being the central point around which is built the imaginary world. This imaginary world, in almost all the African novels, is about the three essential periods of African history: pre-colonial, colonial and post independence. The different efforts deployed by African novelists in their role of "teachers" and their will of arousing consciousness did not succeed in boosting African development as expected though democracy is steadily overpowering the denounced autocratic rules. It is for this reason that I carried out the present analysis so as to indicate a new vision that should govern the thematic choices by African writers, without inhibiting the "fictionality" of their works, in order to actually and efficiently boost Africa in its development. The study is intended to draw Africans' attention on the thematic repetition of the African novels that are past-oriented and to show the technical capacity that the writers have, which can be exploited in the reorientation perspectives, all thing capable of enlarging African literature.

The study starts with the thematic analysis of the African novel by taking into account the above mentioned periods; it goes on with the limitation of the African novel's effect and ends up with my suggestions about a new vision to African novelists related to their thematic choices and their character conception. Technical basis of the analysis is mainly the narratology by Genette (1980) with specific concern with the notion of order relatively to the concept of anachrony and the narrative theory by Chatman (1978) in relation to the elements of a narrative.

The notion of order raises the problem of temporal duality, that is, the temporal difference between the story time and the narrative time in a narrative. The story time is the time related to the different events that constitute the content of a narrative. It is virtually determined in the narration for the reader to uncover. As for the narrative time, it has to do with the time actually managed in narrating the story, the narration which leads to temporal distortions for which the reader must pay intellectual tribute. In those distortions, anachronies constitute the core strategies through which the game is played. There are essentially analyses which occupy the widest room and which are simply the use of the story-past in almost the narration-present and which are commonplace in the narratives. As for 
prolepses, very rare in the narratives, they are used to express anticipations in the normal temporal course of the story, that is, narrating now, events that will come later on in the story.

When such intertwinements are built to form a text, the reader forcibly studies what Genette (1980) calls temporal order, and the study is simply a comparison of "the order in which events or temporal sections are arranged in the narrative discourse with the order of succession these same events or temporal segments have in the story, to the extent that story order is explicitly indicated by the narrative itself or inferable from one or another indirect clue" (Genette, 1980: p. 35). My concern here is to show that it is possible for novelists to create, to imagine a better still fictional society, in better relations with others and in better interactions among themselves. Chinua Achebe's work is the core material of the study in which I would like to show the possibilities of reorienting the thematic choices from the above technical aspects. The coming analysis starts from the presentation of the thematic choices through the different historical periods.

\section{Thematic Choices in African Novels: From the Pre-Colonial Era to Today}

The capacity of imagination of fiction writers in general is so powerful that their work is correlatively true to life. As a consequence, analysts like Killam (1969) easily forget that such a work is fictional. An objective analysis of Achebe's work presents it in comparison with contemporary happenings in society as a social realism that tops up the work with a continued and relative relevance.

\section{Pre-Colonial and Colonial Periods as Seen by Achebe}

The pre-colonial and colonial periods are signalled in the first novel by Chinua Achebe (1958; 1964): Things Fall Apart, and to some extent in Arrow of God, his third novel. Killam (1969: p. 14), about the real life resemblance, writes:

"Things Fall Apart is a vision of what life was like in Iboland between 1850 and 1900. Achebe makes a serious attempt to capture realistically the strains and tensions of the experiences of Ibo people under the impact of colonialism. What ultimately gives this novel its strength is Achebe's feelings for the plight and the problems of that people."

Okonkwo in Things Fall Apart and Ezeulu in Arrow of God perfectly embody the people with their plight and problems until the era of the independences. Achebe has established concrete links with the Ibo past, such an establishment being the condition under which African societies could make meaningful progress, as they can improve that past. In considering Things Fall Apart and Arrow of God as fictions set in the past and taking into account Achebe's own position about what to be written about first, critics found those novels as portraying the virtues of the Ibo society before the arrival of the White. He also portrays superstitious practices of which Taiwo (1976) writes: "Besides the strengths 
in tribal society he [Achebe] gives the weaknesses. We therefore have a true and complete picture in which the whole background is fully realised." Achebe's descriptions of either the forces or the weaknesses of the society are portrayed by showing how individuals fit within the communal life of the society. Achebe also shows that the society he deals with values masculinity, and measures success in terms of personal exploits.

Another aspect in the thematic conception in the same period is the depicting of power abuse. Ezeulu, in Arrow of God, has been presented as the priest, I mean, as a usurpator of Ulu's power, though susceptible of accepting change. In fact, Ezeulu, by accepting to send his son to the white man's school, accepts change contrarily to Okonkwo who even has an attempt to curse Nwoye in Things Fall Apart. This comparison may be taken as unfair when we consider the publishing position of the novels, notably the first and the third novels. But, the researcher considers here the connection of their stories compared to the second novel related to the post independence. Anyway, the extent to which Ezeulu's power is discretionary is in fact the source of his dilemma. This abuse of power is a significant symbol that Achebe indicates in his novels of first generation and of which the post colonial rulers are just the embodiment. It is possible that the reader of Arrow of God surprises himself supporting Ezeulu in his attempts to pay back the communal inaction when he has been in prison, and that he has not been able to roast and eat the month-counting yams, but he must pay attention to the traditional system in which the function of priest is assumed and the new system for which such a function is ignored. And there is the corner where Achebe depicts the limits of the existing harmony among Umuaro people before the arrival of the white.

In fact, in handling his theme of conflict, Chinua Achebe has chosen a tragic medium. The immediate consequence of such a choice is the dramatic ordering of events in which each situation is linked to another with a similar tragic pattern. In Things Fall Apart, for example, the killing of Ikemefuna is narrated in a way or another to the death of the old Ezeudu. The burial ceremony of the old man has followed and has given birth to the inadvertent murder of the son of the dead old man, murder that has sent away Okonkwo from the village. All those events are tragic, but not connected to the arrival of the white man. So, Achebe has depicted an existing society before the arrival of the white man with whom tragic events have continued.

It is with the story in Arrow of God that cultural conflicts start. It is the reason why Arrow of God is considered as the second story of Achebe's trilogy. That novel comes to show the specific treatment of character that Achebe decided to bring to his fiction till then. Achebe succeeded in characterising the individual and the society. This success is all the more important that it reveals a perfect combination of events in relation to individual lives. That combination can be summed up by the schematic tensions between Ezeulu, the chief Priest of Ulu, and Nwaka, a serious rival of the Priest, on the one hand and on the other hand, 
the cultural clash between the chief priest and the white man: "Tell the white man that Ezeulu will not be anybody's chief, except Ulu's."

All the themes concerned with in the pre-colonial and colonial period are in past oriented-stories, that is not totally bad, since the present must draw experience from the past to build the future. The thematic choice of the post independence period can help to appreciate.

\section{Post Colonial Period}

No Longer at Ease and A Man of the People are about the irresponsibility of post colonial rulers in terms of their failure as indigenous administrative class in $N o$ Longer at Ease and the political mess they perpetrate in A Man of the People. Achebe $(1960 ; 1966)$ presents Obi Okonkwo and Chief Nanga as the respective representatives of Nigerians in the two novels. "Achebe's analysis and indictment of the educated elite that were the inheritors of power in the post colonial era have highlighted the underlying reason for their collusion with corrupt political officials, and their own involvement with corruption. He sees both as being due to the unbridled materialism of the society; and the corrupting influence of both privilege and positions of power" as noticed by Ojinmah (1991: p. 87) who believes that Achebe's diagnosis clearly shows that the intelligentsia has been too spineless to resist these temptations, this being the case, in Anthills of the Savannah, of the Commissioner for Justice and Attorney-General, the Commissioner for Education, and even the Commissioner for Information. Such a thematic approach should have brought a great change in the people whose plight and problems are depicted in those novels in particular and in general in the African novel, of course, a fiction is not a fundamental law, but it is supposed to be aspects of the society.

Starting from No Longer at Ease in which the theme of conflict is still topical, the disagreement of Obi with his family in his love adventure with Clara has afforded the crisis in the novel. This is due to the fact that Achebe constructed, in the novel, Obi in a trompe-l'oeil manner. His people have organised and supported his years abroad. It is expected for him to be in societal harmony with his tribe, once back to his home village. But what happens is the advent of a crisis that shows Obi's floundering through his life, at least from the moment his relation with Clara has been known by his family. His hesitation does not stop at the family level between continue the love affair with Clara or abandon her as demanded by the family; it follows him till the moment of the forced corruption. Once again, Achebe presents a tragedy in which, this time, the hero is between tradition and modernity in his double crisis. And once again, the themes are related to depicting experiences enjoyed or suffered by the protagonists of the stories narrated.

The connection of the themes with the realities experienced by Africans is almost a limitation to some possible changes that should yield from the permanent repetition of them by several African writers. From Tutuola (1952) to Adi- 
chie (2013), to be in the same Nigerian context, the thematic conception steps backwards in the stories it goes along with in order to put the reader knee-deep in his/her society's realities so as to bring him/her to a necessary change. But the artistic and imaginative effort of the different writers from Nigeria and Africa, though they play their teaching role, have to do with tough learners who receive without applying what the teacher teaches them: colonial influence, corruption, nepotism, and other evil continue to have office in African countries. The intelligentsia, in fact, has never existed, or has never taken the power. Achebe's view is clear in that he believes that the main problem in contemporary African societies is the lack of restraint in the management of the public power from which African democracy suffers. In proposing the solution to those problems, Achebe believes that a re-formation of the common world of Okonkwo and Ezeulu is necessary. And this re-formation must start from the thematic and structural organisation of the African fiction to come in this outset of the twenty-first century. The researcher's intention is not to take a fictional work as a fundamental law for any African development, law that shows its weaknesses and that needs a revision, it is rather a reflection towards a change that may bring new perspectives of viewing Africa through its literature.

Dealing with the structural organisation of those literary works, the researcher uncovers a kind of antagonism that embodies and clearly shows the weaknesses of the global system to which the protagonists belong. In Things Fall Apart, the characteristic of personal achievement renders Okonkwo famous and honoured, though it does not lead him to a final victory but rather to a tragic end that leaves his people and the white man in a kind of sociolinguistic misunderstanding: "We can take you where he is, and perhaps your men will help us." (P. 146) This symbol is a double irony, the first being an irony of life, the one put forth by the narration, and the second being psychological of which the writer lets the reader appreciate. The appreciation of the researcher here is that the psychological consideration of the irony does not militate in favour of self affirmation of the African people as embodied by the Ibo people in Achebe's conception of it. At the same time collective harmony is overpowered by the attempts to self affirmation, the latter still suffers from the envy of being the one to be praised and not the immediate neighbour. That envy leads to another type of antagonism among the Umuahians.

In Arrow of God, the antagonism is of a different kind and is at three levels. The general struggle against the white man is hindered by two other internal levels of antagonism. The war between Umuaro and Okperi has been the bait through which Achebe portrayed the system of indirect rule. The tension between Ezeulu and Nwaka, though very internal, has played much in the disaggregation of the local union around Ulu, the common deity. The intellectual sense of the chief priest does not help him, though he has sent Oduche to be his eye in the white man's school, to overcome what many critics call "abuse of power". Here again, the Ibo society has lost the combat. The collapse of Obi 
Okonkwo in No Longer at Ease, and the imbroglio that Odili suffers from in $A$ Man of the People essentially are typical examples of disillusionment of Africans related to the amount of hope placed in their local rulers just after the independences. All those thematic choices by the African writers in a natural setting made the African novel sound reactive and realistic, but analeptic, that is, related to what happened and what had happened correspondingly.

It is understandable that the first generation of novels deals with themes about African existence before the arrival of the white, about African realities and even the protest against the false conception of what Africa is in the eye of the white. Professor Odenigbo is aware of that and prepares his new houseboy freshly coming from the village and whom he is looking forward to sending to school in Half of a Yellow Sun. Adichie (2006: p. 11), caricaturing reality wrote:

"There are two answers to the things they will teach you about our land: the real answer and the answer you give in school to pass. You must read books and learn both answers... They will teach you that a white man called Mungo Park discovered River Niger. That is rubbish. Our people fished in the Niger long before Mungo Park's grandfather was born. But in your exam, write that it was Mungo Park."

Though comic in the diction, Chimammanda depicts here the conventionalisation of what the white man thinks or decides about Africa independently from what it actually is.

No African writer is to be blamed for that choice. It is related to the logic of things. In such circumstances, the society, as it is, constitutes the great source of inspiration. Moreover, readers should mirror themselves in those works about the society and for that society in which they are. The normal objectives of the many fiction productions are in that consideration. However, it is now time African writers change, reorient the thematic and structural organisation of their works, still in the perspectives of getting better societal behaviour.

\section{New Perspectives for Thematic and Structural Organisation of the African Novel}

The tendency shown above is about the main themes in the African novel. These themes, in fact, have imposed technical choices to the writers. Essentially, it has been about novels set in Nigeria and in the past, with a clear gradation in that past from Things Fall Apart to Anthills of the Savannah, through Arrow of God, No Longer at Ease and A Man of the People, just deciding to deal with Achebe's work. Taking into account the literary technical orientation by theoreticians, the researcher thinks that a reorientation is possible without much disturbance of the literality of fiction work.

Chatman (1978: pp. 48-49) evokes in the context of the story in a fiction work the notion of "verisimilitude" that governs the notion of "filling in" which singles out for narrative discussion in that it is basic to narrative coherence, that is, writers present narrative for readers and audiences as conventions that they 
come to recognise and interpret by "naturalizing" them. "To naturalize a narrative convention", Chatman wrote, "means not only to understand it, but "to forget" its conventional character, to absorb it into the reading-out process, to incorporate it into one's interpretative net..." The above analysis stepped out from such "naturalization" but past oriented. The different events are analeptically connected, leaving no real room to more positive patterns of the same society. And as such, the interpretative net stays in the same scope.

The new scope for African writers should be on the basis of prolepsis, that is, African writers should deal with themes that portray not an isolated Africa, a hegemonic prey, but rather a united Africa, first in south-south prospering bilateral cooperation, then south-south multilateral or regional cooperation and eventually a reshaped north-south cooperation in which the dice are not to be loaded. Still, Chatman (1978: p. 50) continues to write about the possibility for novelists to write about ideal state of the affairs: "According to structuralists, the norm for verisimilitude is established by previous texts, not only actual discourses, but the texts of appropriate behaviour in the society at large...” That means that it is possible for a novelist to, being aware of what the society is and what it must be for the welfare of its people, imagine a better copy that he/she presents instead of only depicting what it actually is.

New choices are possible and writers do not lack the literary techniques of it. Many scholars and critics of Achebe's works acknowledged it even if most of them focussed on the didactic nature of his writings. Ojinmah (1991: p. 106) is right for such a comment:

Achebe's social and political consciousness preludes the condoning of lapses which verge on squandering of both traditional and inherited political legacies, as is prevalent among the black nations of Africa. As a writer, Achebe has had to recreate his society's historical pasts to counter earlier assumptions that the indigenous peoples did not have any history or culture.

In that context, Achebe surprised himself in the logic of protest as he used the word in an interview by Serumaga (1967: p. 3): "I believe that it is impossible to write anything in Africa without some kind of commitment, some kind of message, some kind of protest."

However, it is necessary to go beyond by evoking the equal capacity that Achebe showed in the setting of his short stories and poems of war. In fact, publishing short stories and poems on the Nigerian Civil War is the evidence that the writer is capable of creating a better Africa through fiction. Achebe was not far from it when he said in the same interview by Serumaga (1967: p. 11):

“Now when I was writing A Man of the People, it wasn't clear to me that this was going to be necessary a military intervention. It could easily have been civil war, which in fact it very nearly was in Nigeria... But I think that all these things the next generation of politicians in Nigeria, when we do have them, will have experienced, and they'll have learned one or two lessons, I hope, from what happened to the First Republic. This is the only hope I have and if it turns out to 
be vain, it would really be terrible."

Of course that civil war was a vindication about which the writer wrote, but, this time, Achebe has been prophetic. And there is the evidence that African writers can fictionally build a better continent, since they have the capacity of writing about events that happen later on in the course of the real Nigerian and African history. The conception of the heroes and the main protagonists of fictions should be organized in a way that gives advance to Odili rather than Chief the Honourable Nanga in A Man of the People.

Still, Achebe (1987), through his last novel, Anthills of the Savannah, extends his structural time sequence to the present. That novel recalls both Achebe's original views and concepts on the role of the writer in African society as evoked in his earlier works. Most importantly, Anthills of the Savannah propounds that role by portraying technical capacities of the writer in the structuring of his views with a clear shift to multiple points of view in the narration. The immediate consequence of which is the distancing of the authorial voice, contrarily to A Man of the People. Taking structurally the writing change brought by Achebe in the conception and realisation of his last novel, one can assert that it is a perfect example of Genette's theory, notably his notions of mood and voice where mood has to do with the particular way the story is narrated, that is, "the different points of view from which life or action is looked at" and voice, "the mode of the action" (p. 213). Achebe succeeded in combining the two aspects in the conception of Beatrice in Anthills of the Savannah. She bears the narrative voice as Ikem and Chris do, but comes to moderate between the views of Ikem and Chris. This technical change is also an ideological change as it shows the writer's improvement of his female vision. Such a change can be operational from the outset and the very outset of the fiction. Percy Lubbock (1921: p. 62), about the transposed terms "showing" and "telling" in the context of narrative, wrote: "The art of fiction does not begin until the novelist thinks of his story as a matter to be shown, to be so exhibited that it will tell itself". That is to say that there is no pure imitation in fiction work, for it to be called artistic and from that corner, the novelist can conceive his/her story with the societal objective that his people wants to live in such an imagined world which is not merely depicted, but rather built on the basis of expectations with the same artistic demands. Concrete examples can be shown through Achebe's (1972; 1977) very works: Achebe's short stories collected under the title "Girls at War and Other Stories" are globally about African daily issues and specifically about survival matters in war time. The collection, purely fictional, is closely transposable to the Biafra war circumstances. Moreover, the writing period is with evidence before 1972, matching more or lessly with the Biafra period (1967-1970). The capacity of dealing with war in a fiction while having suffered a war in real life is evidence that the writer orients his fiction. The same evidence is to some extent in No Longer at Ease with the writer's study process matching Obi's, the hero of the story in the novel. In fact, Chinualumungu Achebe went abroad not to study literature that he actually studied. So, Obi is to some extent Achebe. Considering such evi- 
dence, the researcher found possible to conceive a fiction prospectively.

\section{Conclusion}

In sum, the writing shift made by Achebe in the organisation of his vision about Africa in relation with Africa and with the Western is the evidence that African fiction can be reoriented to a prosperous productive Africa. Through this, the African writer would have been playing his role of Teacher. He has re-established his real past with pride, exposed the invasion with consternation, kept hope and now has to propose a better social entity. As such, Africans would have a new Ezeulu, still fictional, who is capable of making the difference between personal power and communal power; a new Odili, as fictional as possible, as powerful as, maybe, Chief Nanga, the Honourable for the balance of a new Nigeria, new Africa.

The present study did not aim to blame African novelists for their thematic choice, but rather bring the new generation of novelists to go beyond what the old generation did in the domain of writing about Africa for Africa in artistic considerations. In the present study, the analysis about the three periods relative to the thematic contents of most of the novels produced by Africans led to the conclusion that they are essentially concerned with the reaction against some allegation concerning African reality as presented by the white, the same reality as presented by Africans and their disillusionment about their deeds after the departure of the white, deeds that do not meet the expectations of the African peoples. The researcher remarked the common tendency to coming back on the same matters and thought that it is desirable to change a bit in writing about the ideal Africa in which the character-hero does not embody negative power to perform negative actions, but rather a hero capable of overpowering devil forces in the story in which he/she is involved so as to show another corner from which the African society can be boosted to its development. The paper shows the thematic contents of the fictional works by African writers through the example of Chinua Achebe, thematic contents that are in connection with African history. A kind of repetition, in a way or another, is commonly carried out about the African historical realities in the novels. The paper proposes that a change be brought, without altering the "fictionality" of the novels, in the thematic orientation. This may constitute a source of attraction for the African future novels with the expectations that the thematic contents could entice to greater effort of development. However, the paper says nothing about the medium of those novels in which thematic change is expected. Knowing that many of the African written materials are in foreign languages, the language issues in Africa deserve a great attention.

\section{References}

Achebe, C. (1958). Things Fall Apart. London: Heinemann.

Achebe, C. (1960). No Longer at Ease. London: Heinemann. 
Achebe, C. (1964). Arrow of God. London: Heinemann.

Achebe, C. (1966). A Man of the People. London: Heinemann.

Achebe, C. (1972). Girls at War and Other Stories. London: Heinemann.

Achebe, C. (1977). An Image of Africa: Racism in Conrad's "Heart of Darkness". Massachusetts: The Massachusetts Review, Vol. 18.

Achebe, C. (1987). Anthills of the Savannah. London: Heinemann.

Adichie, N. C. (2006). Half of a Yellow Sun (p. 11). Lagos: Farafina.

Adichie, N. C. (2013). Americanah. New York: Alfred Kopf.

Chatman, S. (1978). Story and Discourse: Narrative Structure in Fiction and Film (pp. 48-50). Ithaca and London: Cambridge University Press.

Genette, G. (1980). Narrative Discourse: An Essay in Method (pp. 35, 213). J. E. Lewin, Trans. Ithaca, New York: CUP.

Killam, G. D. (1969). The Novels of Chinua Achebe (p. 14). London: Heinemann.

Lubbock, P. (1921). The Craft of Fiction (p. 62). London: Travellers' Library.

Ojinmah, U. (1991). Chinua Achebe, New Perspectives (pp. 87, 106). Ibadan: Spectrum Books Limited.

Serumaga, R. (1967). Cultural Events in Africa (pp. 3, 11) (Reprinted by Duerden and Pieterse in 1972).

Taiwo, O. (1976). Culture and the Nigerian Novel. St. New York: Martin's Press.

Tutuola, A. (1952). The Palm-Wine Drinker. London: Faber and Faber. 